\title{
The Effect of Price Discounts and Packaging Bonuses on Impulsive Purchasing Decisions to Consumers of Alfamart In Sunter Jaya, North Jakarta
}

\author{
Trinik Susmonowati ${ }^{1}$ Ida Royani ${ }^{2}$ \\ ${ }^{12}$ The STIAMI Institute of Social Sciences and Management \\ Correspondent: triniks@yahoo.com
}

Submitted : September 25, $2020 \quad$ Revised : October 17, $2020 \quad$ Published $\quad$ October 31, 2020

\begin{abstract}
This study aims to determine the magnitude prices effect of discounts and packaging bonus at Alfamart in Sunter Jaya, North Jakarta. The population in this study were all Alfamart customers in Sunter Jaya, North Jakarta with a sample of 130 respondents by using the accidental sampling technique. The data collection technique used is questionnaires, for each respondent given 26 statements. Based on hypothesis testing using $t$ test, price discount and packaging bonus are positive and significant for impulsive purchasing decisions. The results of the $f$ test show that all the independent variables in this study significantly influence impulsive purchasing decisions. $\mathrm{R}$ square value is 0.815 which can be interpreted that the effect of variable $\mathrm{x}$ (price discount and packaging bonus) on the variable y (impulsive purchase decision) is $81.5 \%$, while the remaining $18.5 \%$ is influenced by variables outside the variables studied.
\end{abstract}

Keyword: Price Discount, Packaging Bonus, Impulsive Buying Decision

\section{INTRODUCTION}

Currently, the development of the retail business in Indonesia is very fast. The rapid development of modern retail is based on the company's desire to meet the needs of its customers. Currently, the function of modern retail is not just a place for shopping, but also as a place for family recreation. Retail business is a business activity that sells daily necessities in the form of products and services aimed at consumers for personal or family use. Modern market is described simply as a place to sell food or non-food items, finished goods or processed materials, daily necessities or others that use a self-service format and run a self-service system, where consumers pay at the cashier that has been provided.

There are many modern retail companies in Indonesia, one of them is PT. Sumber Alfaria Trijaya with the name of the outlet, Alfamart, which carries a minimarket business concept. Currently Alfamart has many outlets that have been spread in various regions and regions in Indonesia.

In purchasing decisions, consumers have a variety of different behaviours and often change in deciding a purchase. From a planning perspective, consumer purchases can be categorized into planned purchasing and unplanned purchasing. Planned purchases are buying behaviour where decisions about the items to be purchased have been taken before consumers enter the store. Meanwhile, unplanned purchases are sudden buying behaviour without any prior planning when 
The Effect of Price Discounts and Packaging Bonuses on Impulsive Purchasing Decisions to Consumers of Alfamart In Sunter Jaya, North Jakarta

Susmonowati \& Royani entering a store. As most people experience, they often shop more than originally planned. In fact, sometimes many buy items that are not included in the shopping list that has been prepared.

Consumer purchasing behaviour towards unplanned shopping or impulse buying is a phenomenon that attracts the attention of producers and retailers in today's modern market. The phenomenon of "impulse buying" is certainly something that must be used by producers and retailers. Taking advantage of consumer behaviour and emotions is attractive to producers and retailers. Because emotionally interested consumers often no longer involve thoughts in the process of making a purchase decision for an item.

In June 2013, Nielsen reported on a research study that Indonesian consumers are increasingly impulsive in shopping. There are several indications that indicate this. The results of this survey were obtained through direct interviews with 1,804 respondents in 5 major cities in Indonesia, namely Jakarta, Bandung, Surabaya, Makassar and Medan. The survey results indicated that the impulsive buying trend of Indonesian consumers tends to increase every year.

Factors that influence impulse buying include those taken in this study are discounts and bonus packs, in an era of intense competition like this, companies must pay attention to the price factor, because the size of the price greatly affects a company's competitive ability and influence consumers to buy their products. The purpose of providing discounted prices is to encourage large purchases, encourage purchases to be made in cash or a shorter time (impulse buying), and bind customers so they don't move to other companies. This is generally used by companies to persuade existing users to buy more, encourage new product users or convince consumers to try existing products. In addition, price discounts are sufficient to get a fast response from consumers, this can be seen by consumers' enthusiasm if there is a price discount, such as in department stores, and consumers pay more attention to products that are discounted than products with normal prices.

According to research conducted by Meigie Putri Dalihade, James D. D Massie, and Maria V. J Tielung with the title "The Effect of Discounts and Store Atmosphere on Impulse Buying at Matahari Department Strore Mega Mall Manado" (2017), they stated that the discount price has a positive and significant effect on impulse buying.

Apart from the discount factor, bonus packaging can also influence impulsive buying decisions. According to research conducted by Revie. CT Waani and Willem JF Alfa Tambunan with the title "The Influence Of Price Discount, Bonus Pack, and In-Store Display On Impulse Buying Decision In Hypermart Kairagi Manado" (2015) they stated that bonus packs had a significant contribution or quite dominant influence in terms of consumer behavior in impulse buying.

To make an unplanned purchase (impulse buying), consumers will usually first enter the store looking for and evaluating the information contained therein, such as information on discounts and bonus packages, sometimes consumers will try and compare products. products that are the center of his attention. Along with the many alternatives that are seen by the five senses, the concentration that is focused on the purchase that has been previously planned will become divided and there will be a feeling of interest in other products that were not previously planned.

From this background, the authors are interested in researching more about the factors that influence impulsive purchasing decisions on consumers of Alfamart in Sunter Jaya. The author will 
The Effect of Price Discounts and Packaging Bonuses on Impulsive Purchasing Decisions to Consumers of Alfamart In Sunter Jaya, North Jakarta

Susmonowati \& Royani

pour into a study entitled "The Effect of Price Discounts and Packaging Bonuses on Impulsive Purchasing Decisions to Consumers of Alfamart in Sunter Jaya, North Jakarta".

According to Fahmi Irham (2015: 1) "Administration is a systematically structured relationship building in the form of a network that collaborates with each other to support the realization of a structured work mechanism and achieve the expected goals". Daryanto (2011: 1), "This administration comes from the Latin words ad and ministro. Ad means to and Ministro means to serve. Freely it can be interpreted that administration is a service and dedication to certain subjects.

According to Handoko (2011: 8), management is the process of planning, organizing, directing and supervising the efforts of organizational members and the use of organizational resources and use of other organizational resources in order to achieve established organizational goals. R. Terry (2013: 15) Management is a typical process consisting of planning, organizing, mobilizing and controlling actions that are carried out in determining and achieving predetermined targets through the use of human resources and others.

In general, each company adheres to one marketing concept or philosophy, namely the philosophy or assumption that the company believes is the basis of its activities in satisfying needs and experiencing development or evolution of thought. However, it does not mean that the latter concept is the best.

According to Djaslim S in the book Nana Herdiana (2015: 129) marketing is a total system of business activities designed to plan, determine prices, promote, distribute goods that can satisfy desires and achieve target markets and company goals. Kotler (2012: 14) marketing is a social process with and wants by creating and exchanging production and value with other individuals and groups. Buchori and Djaslim (2010: 5), marketing management is a process of planning and implementing conceptions, pricing, promotion and distribution of ideas, goods, and services to produce exchanges that satisfy individuals and meet organizational goals.

Price discount or sales discount is a price discount if payment is made earlier than the credit period (Soemarso, in Kasimin et al 2014: 5). Discounts (sales discounts) are cash discounts offered to customers who buy goods on credit (Simamora, in Kasimin et al 2014: 5). Sales discount is a discount on the approved sales price if the payment is made in a period that is faster than the credit period or cash discount when viewed from the seller's point of view (Ismaya, in Kasimin et al 2014: 5).

Bonus packs are additional products from the company to be given to consumers at the same price so as to create satisfaction in shopping. According to Belch \& Belch (2009) bonus packs offer consumers an extra load of a product at a normal price. This promotion can be used to increase impulse buying by consumers.

Solomon \& Rabolt (2009) stated that impulse buying is a condition that occurs when an individual experiences a sudden feeling of urgency that cannot be resisted. This tendency to buy spontaneously generally can result in purchases when consumers believe that the action is a natural thing (Rook \& Fisher in Solomon 2009).

According to Iyer (in Kharis, 2011), impulsive buying is a fact of life in consumer behavior which is proven as a purchasing activity related to the environment and limited time in shopping, where the route of purchase they do should be different. This route can be distinguished by an 
The Effect of Price Discounts and Packaging Bonuses on Impulsive Purchasing Decisions to Consumers of Alfamart In Sunter Jaya, North Jakarta

Susmonowati \& Royani impulsive hierarchy which observes that behavior is based on an effective response that is influenced by strong feelings (Mowen \& Minor, in Kharis 2011), so that impulsive buying according to Hoch et al., Occurs when there is a very strong positive feeling then followed by the buying attitude.

London and Bitta (in Anin, 2012) reveal the factors that influence impulsive buying, namely: (1) Products with the characteristics of low prices, small or marginal needs, short-term products, small sizes, and easily accessible stores; (2) Marketing and marketing, which includes distribution in a large number of self-service outlets, highly suggestible and continuous advertising through mass media, point of sale advertisements, display positions and prominent store locations; and (3) Consumer characteristics such as personality, gender, socio-demographic or socioeconomic characteristics

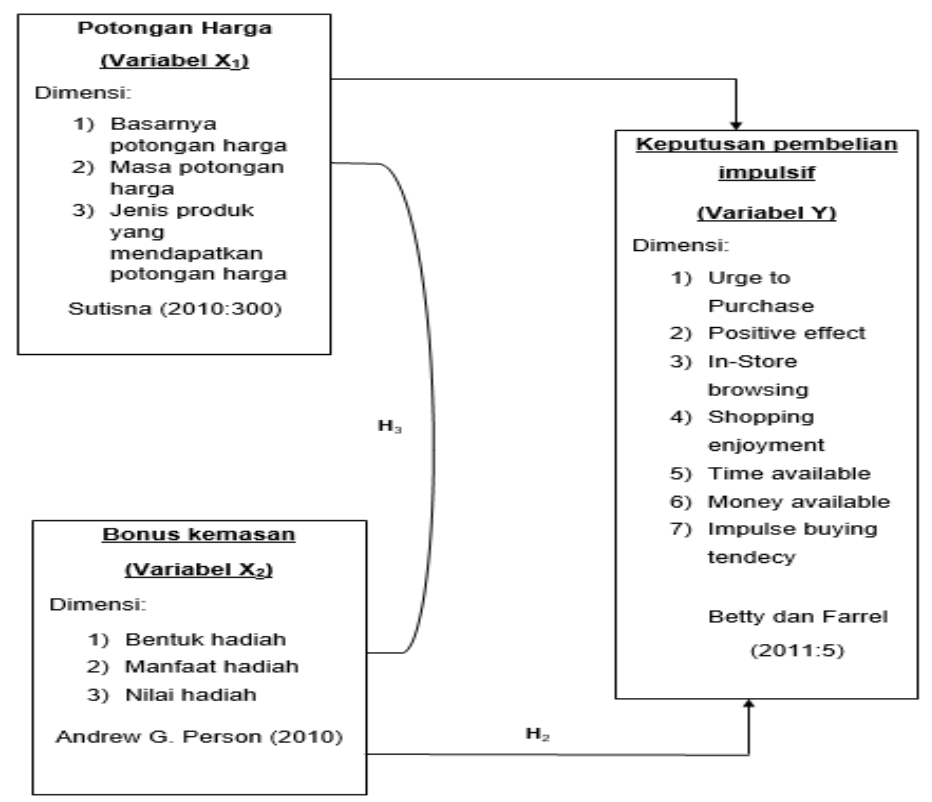

Figure 1. Theoretical Framework

\section{METHODS}

This study uses a causality research approach to analyze the causal relationship between variables through hypothesis testing (Sugiyono 2012: 24). The method used in this research is quantitative method. Quantitative methods use a number of samples and numerical data.

Data collection techniques are tools used to obtain data used to obtain the data needed in a study. According to Sugiyono (2012: 162), said: "The questionnaire is a data collection technique which is done by giving a set of questions or written statements to the respondent to answer". To measure the results of respondents' responses, a scale is used.

Literature study is conducted to obtain secondary data by studying, researching and reviewing several literature books, journals, papers, websites, websites, and previous studies related to the problem being researched and then reprocessed. 
The Effect of Price Discounts and Packaging Bonuses on Impulsive Purchasing Decisions to Consumers of Alfamart In Sunter Jaya, North Jakarta

Susmonowati \& Royani

According to Sugiono (2012: 57) population is a data source of the generalization area consisting of objects or subjects that have certain quantities and characteristics that are determined by researchers to be studied and then draw conclusions. In this study, the population is all customers who make purchases at Alfamart Sunter Jaya, North Jakarta. Sugiono (2012: 57), the sample is part of the number and characteristics possessed by the population. The method used was the Accidental Sampling method, which was random sampling. Representatives of the population sample are consumers of Alfamart Sunter Jaya, North Jakarta. In taking samples, researchers have searched for methods that are in accordance with this study, because the population is not known or changes frequently, so for sampling using the opinion of Hair et al (2010: 112), states that "if the population is unknown, the number of samples. the minimum is 5 times the number of question items contained in the questionnaire ". The total number of questions in this study was 26 , so the sample calculation results were obtained as follows: Number of samples $=26 \times 5=130$ samples So for the sample taken in this study there were 130 people.

\section{RESULTS AND DISCUSSION}

\section{The Effect of Discounts on Impulsive Purchasing Decisions}

The results showed that there was a positive and significant influence between price cuts (X1) on impulsive buying decisions (Y). Impact from discount (X1) is 0.373 or $37.3 \%$. The conclusion that can be drawn is that price discounts have a positive and significant effect of $37.3 \%$ on impulsive buying decisions at Alfamart Sunter Jaya, North Jakarta. These results are in line with previous research conducted by Revie. C. T Waani (2015) where pongan price has a positive and significant effect on impulsive buying decisions. Basically, discounts have a considerable influence in influencing consumers to make impulsive buying decisions. Where the larger the discount, the greater the desire of consumers to make impulsive buying decisions.

\section{The Effect of Bonus Packaging on Impulsive Purchasing Decisions}

The results showed that there was a positive and significant effect between bonus packaging (X2) on impulsive buying decisions (Y). The influence of the packaging bonus (X2) is 0.809 or $80.9 \%$. The conclusion that can be drawn is that bonus packaging has a positive and significant effect of $80.9 \%$ on impulsive buying decisions at Alfamart Sunter Jaya, North Jakarta. This result is in line with previous research conducted by Andriani Kusuma (2018), where bonus packaging has a positive and significant effect on impulsive buying decisions. Basically, the packaging bonus can attract consumers to make purchases, the more attractive the packaging bonuses are, the more consumers want to make a purchase.

\section{The Effect of Discounts and Package Bonuses on Impulsive Purchasing Decisions}

The results show that simultaneously there is a positive and significant effect between discounted prices (X1) and bonus packages (X2) on impulsive buying decisions (Y). The effect of discounted prices and packaging bonuses simultaneously on impulsive buying decisions shows that it is 0.815 or $81.5 \%$. The variable of impulsive purchasing decisions at Alfamart Sunter Jaya, North Jakarta is influenced by these two independent variables. The conclusion is that discounts and packaging bonuses have a positive and significant effect of $81.5 \%$ on impulsive buying decisions at Alfamart Sunter Jaya, North Jakarta, while the remaining $18.5 \%$ is determined by other variables that 
The Effect of Price Discounts and Packaging Bonuses on Impulsive Purchasing Decisions to Consumers of Alfamart In Sunter Jaya, North Jakarta

Susmonowati \& Royani

are not included in this study. The results of this study are also in line with previous research conducted by Meigie Putri Dalihade (2017), which explains that price discounts and packaging bonuses have a positive and significant effect on impulsive buying decisions. Therefore, it can be concluded that discounts and packaging bonuses can attract consumers to make impulsive purchases. companies can use promotional media through discounted prices and bonus packaging to attract consumers to make impulsive buying decisions.

\section{CONCLUSION}

There is a positive and significant effect of price discounts on impulsive buying decisions at Alfamart Sunter Jaya, North Jakarta, amounting to $37.3 \%$.

There is a positive and significant effect of bonus packaging on impulsive buying decisions at Alfamart Sunter Jaya, North Jakarta, amounting to $80.8 \%$.

There is a positive and significant effect of price potogan and packaging bonuses on impulsive decisions at Alfamart Sunter Jaya, North Jakarta, amounting to $81.2 \%$, while the remaining $18.8 \%$ is determined by variables not included in this study.

From existing data regarding price discounts, there are 2 discount variable indicators that have a value below the average (3.79), namely the price indicators obtained are much cheaper with a value (3.64) and a limited discount time with a value (3.45). The suggestion from researchers is to increase the discount price and extend the discount period so that consumers can enjoy the promo freely. By attracting consumers with large discounts on old stock items that are still fit for use.

From the existing data regarding the packaging bonus, there are 2 indicators of packaging bonus variables that have a value below the average (3.76), namely an attractive shape indicator with a value (3.43) and the size of the gift according to the value (2.88). ). The suggestion from the researcher is that Alfamart Sunter Jaya must be able to choose what bonus gifts are appropriate to be given as a product bonus that is being offered by choosing an attractive shape and the appropriate size.

Based on existing data regarding impulsive purchasing decisions, there are 5 indicators of impulsive purchasing decision variables that have an average value (4.10), namely indicators of feeling sorry if you don't buy a product with a value (4.08), interest in the product. with a value (4.04), like to shop with a value (3.99), available free time with a value (3.92), and deliberately bringing more money with a value (3.98). The suggestion from the researchers is that Alfamart Sunter Jaya should be able to attract consumers to make impulsive buying decisions by providing

promos such as attractive discounts and bonus packaging. And continue to innovate in determining attractive promos.

\section{REFERENCES}

Ali, Faried. (2013). Ilmu Administrasi Negara. Jakarta:Pustaka Setia.

Abdurrahman, \& Nana Herdisns. (2015). Manajemen Strategi Pemasaran. Bandung: Pustaka Raya. Daryanto. (2011). Manajemen Pemasaran. Bandung: PT. Sarana Tutorial Nurani Sejahtera. Fahmi, Irham. (2015). Pengantar Ilmu Administrasi Bisnis. Bandung: Alfabeta 
The Effect of Price Discounts and Packaging Bonuses on Impulsive Purchasing Decisions to Consumers of Alfamart In Sunter Jaya, North Jakarta

Susmonowati \& Royani

Kotler, Philip \& Amstrong. (2008). Prinsip-Prinsip Pemasaran. Edisi 12. Jilid 1. Alih Bahasa: Bob Sabran. Jakarta: Erlangga.

Kotler, Philip. (2007). Manajemen Pemasaran, edisi ke 12, Jilid 1, Jakarta: PT. Indeks Kelompok Gramedia.

Riduan. (2009). Pengantar Statistika. Bandung : Alfabeta

Siagian, Sondang P. (2008). Filsafat Administrasi. Cetakan ketiga. Jakarta:Rineka Cipta.

Siagian, Sondang P (2008). Administrasi Pembangunan Konsep, Dimensi, dan Strategi. Jakarta: Haji Masagung.

Sugiono. (2012). Metode Penelitian Kuantitatif Kualitatif dan R\&D. Bandung: Alfabeta.

Soemantri, Ating. \& Sambas Ali Muhidin. (2006). Aplikasi Statistika dalam penelitian. Bandung : CV Pustaka Setia. 